\title{
7. MAGNETIC PROPERTIES AND PALEOMAGNETISM OF BASALTS FROM LEG 107 (HOLES 651A AND 655B) $)^{1}$
}

\author{
L. Vigliotti, ${ }^{2}$ M. Torii, ${ }^{3}$ and J. Channell ${ }^{4}$
}

\begin{abstract}
The basalts recovered at Holes 651A and 655B appear to carry a single component remanent magnetization, which is generally of reversed polarity. These magnetizations are consistent with eruption during the Matuyama $(651 \mathrm{~A})$ and Gilbert (655B) polarity epochs.

The blocking temperature spectra and the $\mathrm{J} s / \mathrm{T}$ curves indicate that titanomaghemite is the principal remanence carrier. The lower mean destructive field (MDF) and higher susceptibility at 651A probably indicates a lower mean oxidation state at this hole relative to $655 \mathrm{~B}$, which may simply reflect the age difference between the two basalt sequences. At both holes, a decreasing downcore trend both in natural remanent magnetization (NRM) and susceptibility probably indicates that maghemitization (from primary titanomagnetite) increases downcore. An interval of high coercivity at hole 655B (119.80-151.45 mbsf) appears to define a magnetically distinct unit within the basalt sequence.
\end{abstract}

\section{INTRODUCTION}

This study reports the magnetic properties and the paleomagnetic measurements of 85 basalt samples recovered during Leg 107 (Tyrrhenian Sea) at Hole 651A (Vavilov Basin, 17 samples) and 655B (Gortani Ridge, 68 samples). About $110 \mathrm{~m}$ of basalts were recovered at Hole $655 \mathrm{~B}$. The basalts were composed of many pillow flows, with a mean thickness for each flow of about $2 \mathrm{~m}$. Carbonate filled fractures and veins were common in the upper $30 \mathrm{~m}$ of the basalts and were less frequently observed at lower depths. At least one sample from each basaltic flow was obtained in the section 655B.

The basement drilled at Hole 651A consists of a complex rock assemblage that has been divided into four units: (1) Upper basalts, from 386 to $464 \mathrm{~m}$ below seafloor (mbsf) consisting of several flows with a tholeiitic to intermediate affinity, (2) Dolerites and metadolerites drilled from approximately 464-492 mbsf, (3) Lower basalts and basaltic breccias recovered from 492 to 522 mbsf. These basalts appear similar to those of the first unit, and (4) Serpentinized peridotites drilled from 522 mbsf to the bottom of the section, at 551 mbsf. A total of 14 samples of unit (1) and 3 of unit (4) were studied. All specimens (cubes $2 \times 2 \times 2 \mathrm{~cm}$ ) were oriented with respect to the vertical. A number of magnetic properties were measured: initial susceptibility $(\mathrm{K})$, intensity and direction of natural remanent magnetization (NRM), isothermal remanent magnetization (IRM), anisotropy of magnetic susceptibility (AMS). In addition, the NRM and IRM of some samples were thermally demagnetized, thermomagnetic analyses were performed and opaque mineralogy was examined. Routine paleomagnetic measurements on about half the Hole 655B samples were made by the shipboard party (J. Channell and M. Torii) on the JOIDES Resolution. Remaining measurements were carried out in the Paleomagnetic Lab of the Istituto di Geologia Marina of CNR of Bologna (Italy).

\footnotetext{
${ }^{1}$ Kastens, K. A., Mascle, J., et al., 1990. Proc. ODP, Sci. Results, 107: College Station, TX (Ocean Drilling Program)

2 Istituto di Geologia Marina CNR, 40127 Bologna, Italy.

3 Department of Geology and Mineralogy, Kyoto University, Kyoto 606, Japan.

${ }^{4}$ Department of Geology, University of Florida, Gainesville, FL 32611.
}

Some AF demagnetizations and saturations of remanence (IRM) were carried out in the Paleomagnetic Lab of the Centre des Faibles Radioactives CNRF of Paris (France). Thermomagnetic curve measurements were performed in the Ocean Research Institute of the University of Tokyo (Japan). Apart from the measurements on the ship, the intensity of remanence (NRM) was measured by a Jelinek JR-4 spinner magnetometer. The susceptibility $(\mathrm{K})$ and the anisotropy of the magnetic susceptibility (AMS) was measured using a Jelinek Kappa bridge.

\section{NATURAL REMANENT MAGNETIZATION (NRM)}

Natural remanent magnetization intensities ( $\mathrm{Jr}$ ) generally range from 1.7 to $12.1 \mathrm{~A} / \mathrm{m}$ in Hole $651 \mathrm{~A}$ and from 0.113 to $14.9 \mathrm{~A} /$ $\mathrm{m}$ in Hole 655B (Tables 1 and 2, Figs. 1 and 2). In both holes the intensities become weaker and the scatter decreases in the lower part of the section. In Hole 651A the decrease of $\mathrm{Jr}$ appears to coincide with a petrographically distinct boundary in the upper basalts. In Hole 655B, the remanence shows two steplike decreases from the top to the bottom. In detail it follows three trends: (1) from $81.35 \mathrm{~m}$ through $105.17 \mathrm{~m}$, it is very scattered ranging from 1.6 to $14.9 \mathrm{~A} / \mathrm{m}$ (mean $6.65 \mathrm{~A} / \mathrm{m}$ ); (2) from 110.24 through $149.19 \mathrm{~m}, \mathrm{Jr}$ is less scattered, with mean intensity of $2.65 \mathrm{~A} / \mathrm{m}$; and (3) from 151.17 through $191.93 \mathrm{~m}$, the intensities are more homogeneous and much weaker (mean 0.86 $\mathrm{A} / \mathrm{m}$ ). Apart from 10 samples from Hole $655 \mathrm{~B}$ which were thermally demagnetized, the whole collection has been stepwise demagnetized using alternating fields.

The orthogonal projections of alternating field demagnetizations suggest the presence of a single magnetization component (Fig. 3). The cleaned inclinations from Hole 655B (Fig. 4A) are consistent with the latitude of the site. In Hole 651A the inclinations are systematically shallower and scattered (Fig. 4B) suggesting the possibility of tectonic disruption. The inclinations from both sites are generally negative. In view of the magnetization of overlying sediments at both sites, the reversed magnetizations in the basalts most probably correspond to Matuyama for Hole 651A and Gilbert for Hole 655B. In 655B (Fig. 4A), three intervals of normal polarity magnetization are indicated. The significance of these data is unclear. They may indicate records of three normal polarity intervals in the Gilbert, but this is very uncertain in view of the small number of samples which define these normal intervals. 
Table 1. Magnetic properties of basalts recovered at Hole 651A. Symbols: K, magnetic susceptibility ( $\times 10^{-6}$ S.I. units). J(R), intensity of Natural Remanent Magnetization (NRM). Q, Koenigsberger ratio. I, stable inclination after demagnetization. MDF, Median Destructive Field of NRM. J(Rs), Saturation Remanence. P, factor of Anisotropy.

\begin{tabular}{lccccrccc}
\hline $\begin{array}{l}\text { Core, section, } \\
\text { interval }(\mathrm{cm})\end{array}$ & $\begin{array}{c}\text { Depth } \\
\text { (mbsf) }\end{array}$ & $\begin{array}{c}\mathrm{K} \\
\times 10^{-6}\end{array}$ & $\begin{array}{c}\mathrm{J}(\mathrm{R}) \\
\mathrm{A} / \mathrm{m}\end{array}$ & $\mathrm{Q}$ & $\mathrm{I}$ & $\begin{array}{c}\mathrm{MDF} \\
\mathrm{mT}\end{array}$ & $\begin{array}{c}\mathrm{J}(\mathrm{Rs}) \\
\mathrm{A} / \mathrm{m}\end{array}$ & $\begin{array}{c}\mathrm{P} \\
\mathrm{K} 1 / \mathrm{K} 3\end{array}$ \\
\hline 42R-1, 20-22 & 386.71 & 6388 & 6.17 & 26.9 & 9 & 15.9 & 86.3 & 1.004 \\
42R-1, 130-132 & 387.81 & 4415 & 6.63 & 41.8 & 52 & 18 & 145 & 1.013 \\
43R-1, 133-135 & 387.54 & 6262 & 12.14 & 54.2 & -18 & 18.4 & 220 & 1.013 \\
44R-1, 20-24 & 406.12 & 4788 & 1.7 & 8.8 & -31 & 10.5 & 68.5 & 1.012 \\
44R-1, 130-132 & 407.21 & 4127 & 6.51 & 24.5 & -35 & 18.7 & 123 & 1.016 \\
44R-2, 40-42 & 407.81 & 5144 & 5.76 & 31.3 & -37 & 17.3 & - & 1.013 \\
44R-2, 136-138 & 408.77 & 4475 & 7.76 & 48.1 & 22 & 23.8 & 144 & 1.011 \\
45R-1, 56-5S & 416.17 & 5088 & 8.34 & 45.8 & -30 & 20.6 & 191 & 1.006 \\
46R-1,11-13 & 425.42 & 3655 & 8.12 & 61.7 & -53 & 22 & 141 & 1.011 \\
46R-1, 87-88 & 426.18 & 3580 & 4.74 & 37 & -40 & 16.1 & 90.8 & 1.028 \\
47R-1, 46-48 & 435.47 & 5274 & 3.85 & 20.4 & -28 & 17.6 & 129 & 1.006 \\
47R-1,126-128 & 436.26 & 7432 & 9.33 & 35.1 & -8 & 16.9 & 181 & 1.009 \\
49R-1, 76-78 & 455.07 & 5920 & 1.75 & 8.3 & -27 & 25.6 & 165 & 1.009 \\
49R-1, 141-143 & 455.72 & 365 & 0.005 & 0.4 & -47 & 27.8 & 0.54 & 1.008 \\
53R-1,113-114 & 494.02 & 533 & 0.212 & 11.2 & 5 & 15.3 & 8.2 & 1.013 \\
53R-2, 98-100 & 495.38 & 10185 & 2.98 & 8.2 & -6 & 7.9 & 104 & 1.012 \\
53R-2, 112-114 & 495.52 & 10956 & 3.21 & 8.2 & -15 & 10.8 & 114 & 1.01 \\
Mean & & 5212 & 5.25 & 27.9 & -26 & 17.9 & 120 & 1.011 \\
\hline
\end{tabular}

\section{MAGNETIC SUSCEPTIBILITY (K) AND KOENIGSBERGER RATIOS (Q)}

The magnetic susceptibility $(\mathrm{K})$ is controlled by the volume concentration of ferromagnetic minerals as well as by the grain size and other parameters like stress, etc. The magnetic susceptibility of Hole $651 \mathrm{~A}$ (mean $5212 \times 10^{-6}$ S.I. units) (Fig. 5) is about 2.5 times higher than that of Hole 655B (mean $1940 \times$ $10^{-6}$ S.I. units) (Fig. 6). Only in a few cases does the susceptibility correlate with NRM intensities. Although the scatter in susceptibility is less than for the NRM intensity, the susceptibility values show a pattern similar to Jr. In Hole 655B, the general trend is for higher susceptibility in the upper part of the section and lower values near the bottom (Fig.6).

The distribution of the Koenigsberger ratios (Q) in both holes (Figs. 7 and 8) resembles that of the NRM. Although the intensities of the remanence of the two sites are comparable, Hole 651A has a higher mean susceptibility, and consequently the Koenigsberger ratio of Hole 651A (mean 27.9) is lower than that of the Hole 655B (mean 52.4). In the lower part of this hole (deeper than 158.76), Q is about 15 times lower than in the initial $14 \mathrm{~m}$ of core. The Koenigsberger ratio is greater than 1.0 in all the samples with only two exceptions in Hole 651A. One of these samples is a brecciated basalt chunk in a limestone matrix (53R-01, 113-114), and the other is a basalt affected by the process of albitization (49R-01, 141-143). All the magnetic properties of both these samples are apart from normal values. The high values of $\mathrm{Q}$ demonstrate that remanence dominates induced magnetization, and that remanence is the principal cause of the magnetic anomaly $(170 \mathrm{nT})$ observed at sea surface over the Gortani Ridge (Hole 655B).

\section{MEDIAN DESTRUCTIVE FIELD (MDF) OF NRM}

The coercivity of NRM is characterized by the median destructive field (MDF), defined as the peak alternating field necessary to reduce the NRM intensity to $50 \%$ of its initial value. Like the remanence and susceptibility, the coercivity is sensitive to magnetic grain size. It is well known that the median destructive field for fine-grained basalts is distinctly higher than that for coarser-grained basalts. This magnetic property is significantly different in the two studied sections. The MDF of Hole $651 \mathrm{~A}$ (Fig. 9) is scattered about a mean value of $17.9 \mathrm{mT}$. In
Hole $655 \mathrm{~B}$ the MDF ranges from 11.7 to $94 \mathrm{mT}$ with an overall mean of $40.4 \mathrm{mT}$ (Fig. 10). In the middle part of this section (from 119.80 through $151.45 \mathrm{mbsf}$ ), the MDF is more scattered than at the top and bottom. Moreover, the middle part of the section gives a higher mean value $(52.8 \mathrm{mT})$. The MDF of the basalts from Hole $651 \mathrm{~A}$ is quite consistent with the value of $14.5 \mathrm{mT}$ measured by Lowrie (1977) on a collection of DSDP basalts, but the mean MDF of the Hole 655B is higher, but consistent with the MDF range between 23 and $104 \mathrm{mT}$ found by Ade-Hall et al. (1976).

As shown in Figure 11, there is a correlation between the MDF and the susceptibility; high values of MDF match well with low susceptibilities.

The coercivity is not only a function of the grain size, but also of the degree of oxidation (titanomaghemitization). Marshall (1978) found that the MDF value of the oxidized basalts is greater (at least $50 \%-100 \%$ ) than the values expected in unoxidized submarine basalts having the same grain size.

\section{ISOTHERMAL REMANENT MAGNETIZATION (IRM)}

IRM acquisition curves were obtained by placing specimens between the poles of an electromagnet whose direct magnetic field was stepwise increased up to 0.8-1.2 T. In general, saturation isothermal remanent magnetization (SIRM) is a function of the magnetic mineral content and the grain size. The observed saturation values (Jrs) range from 68.5 to $220.3 \mathrm{~A} / \mathrm{m}$ in Hole $651 \mathrm{~A}$ with an arithmetic mean of $120.1 \mathrm{~A} / \mathrm{m}$ and from 21.7 to $322.2 \mathrm{~A} / \mathrm{m}$ in Hole $655 \mathrm{~B}$ with an overall mean of 142.2 $\mathrm{A} / \mathrm{m}$. The IRM curves from Hole $651 \mathrm{~A}$ were saturated in a field of $150 \mathrm{mT}$ and occasionally in fields as low as $50 \mathrm{mT}$ (Fig. 12A). Sample 49R-01, 141-143 was the only one of the whole collection to acquire a magnetization in a field as strong as 1.0 T. For Hole $655 \mathrm{~B}$, two patterns can be distinguished. Samples from the top of the section through $111.81 \mathrm{mbsf}$ and samples deeper than $158.76 \mathrm{mbsf}$ were saturated in a peak-field of $0.2 \mathrm{~T}$, while samples from 119.80 through 151.45 mbsf saturated in higher fields, often up to 0.5-0.6 T (Fig. 12B).

\section{THERMAL DEMAGNETIZATIONS}

Ten basaltic samples from Hole 655B were stepwise thermally demagnetized. The IRM from both holes was subjected to 
Table 2. Magnetic properties of basalts from Hole 655B. Symbols as in Table 1.

\begin{tabular}{|c|c|c|c|c|c|c|c|c|}
\hline $\begin{array}{l}\text { Core, section, } \\
\text { interval }(\mathrm{cm})\end{array}$ & $\begin{array}{l}\text { Depth } \\
\text { (mbsf) }\end{array}$ & $\begin{array}{c}\mathrm{K} \\
\times 10^{-6}\end{array}$ & $\begin{array}{l}\mathrm{J}(\mathrm{R}) \\
\mathrm{A} / \mathrm{m}\end{array}$ & Q & I & $\begin{array}{l}\text { MDF } \\
\mathrm{mT}\end{array}$ & $\begin{array}{l}\text { J(Rs) } \\
\mathrm{A} / \mathrm{m}\end{array}$ & $\underset{\mathrm{K} 1 / \mathrm{K} 3}{\mathbf{P}}$ \\
\hline $1 R-1,14-16$ & 81.35 & 1370 & 4.04 & 82.3 & -57 & 35.5 & 90.6 & 1.009 \\
\hline $1 R-1,143-145$ & 82.64 & 2598 & 11.60 & 124.7 & -8 & 37.2 & 143.8 & 1.007 \\
\hline $1 \mathrm{R}-2,37-39$ & 83.08 & 889 & - & - & - & - & 42.6 & - \\
\hline $1 R-2,110-112$ & 83.81 & 2774 & 12.19 & 149.7 & 54 & 32.2 & - & - \\
\hline $1 R-3,8-10$ & 84.29 & 1302 & 2.55 & 54.7 & -47 & - & - & 1.008 \\
\hline $1 \mathrm{R}-3,105-107$ & 85.26 & 1356 & 4.86 & 100.1 & -55 & - & - & - \\
\hline $1 R-4,63-65$ & 86.34 & 1539 & 11.10 & 201.4 & -54 & 45.5 & 111.7 & 1.012 \\
\hline $1 \mathrm{R}-4,120-122$ & 86.91 & 1019 & 3.74 & 102.5 & -5 & 66.3 & 24.8 & 1.002 \\
\hline $1 R-5,35-37$ & 87.56 & 1678 & 3.32 & 55.3 & 56 & 38.5 & - & 1.013 \\
\hline 1R-5, $140-142$ & 88.61 & 2656 & 1.78 & 18.7 & -55 & 25.4 & 164.6 & - \\
\hline 1R-6, 36-38 & 89.07 & 3564 & 14.86 & 11.6 & -55 & 19.2 & 154.6 & 1.004 \\
\hline 1R-6, 69-71 & 89.40 & 3542 & 9.91 & 78.1 & -56 & 15.1 & 130.0 & 1.010 \\
\hline $2 \mathrm{R}-1,45-47$ & 91.26 & 2797 & 11.67 & 116.5 & -50 & 24.9 & - & 1.007 \\
\hline $2 \mathrm{R}-1,119-121$ & 92.00 & 2330 & 5.02 & 60.2 & -59 & 16.8 & 179.2 & 1.018 \\
\hline 2R-2, 69-71 & 93.00 & 2558 & 10.70 & 119.9 & -45 & - & 205.2 & - \\
\hline $2 \mathrm{R}-2,133-135$ & 93.64 & 2893 & 7.91 & 76.8 & -54 & 20.2 & 270.7 & 1.013 \\
\hline $2 \mathrm{R}-3,103-105$ & 94.84 & 2548 & 9.55 & 156.7 & -47 & 33.6 & 204.0 & 1.014 \\
\hline $2 \mathrm{R}-3,113-115$ & 94.94 & 1562 & 4.41 & 78.9 & -52 & 48.2 & 130.0 & 1.011 \\
\hline $2 R-4,28-30$ & 95.59 & 2380 & 1.62 & 1.9 & -58 & 32.8 & 120.2 & 1.003 \\
\hline $3 R-1,40-42$ & 100.81 & 2374 & 2.31 & 27.2 & -47 & 26.9 & - & - \\
\hline $3 R-2,113-115$ & 103.04 & - & 10.20 & - & - & 53 & 37.3 & 154.8 \\
\hline $3 \mathrm{R}-3,104-106$ & 104.44 & 5570 & 4.10 & 20.6 & -43 & 15.1 & 322.2 & - \\
\hline $3 R-4,26-28$ & 105.17 & 4990 & 1.62 & 9.1 & -51 & 11.7 & 213.5 & 1.012 \\
\hline $4 \mathrm{R}-1,23-25$ & 110.24 & 2145 & 3.89 & 6.6 & -58 & 44.5 & 209.9 & 1.005 \\
\hline $4 \mathrm{R}-1,116-118$ & 111.17 & - & 4.59 & - & -60 & - & - & - \\
\hline $4 \mathrm{R}-2,30-32$ & 111.81 & 2075 & 0.14 & 1.9 & -42 & 31.6 & 55.9 & 1.007 \\
\hline $4 R-2,105-107$ & 112.56 & 1415 & 2.64 & 52.2 & -61 & - & 102.2 & 1.014 \\
\hline 5R-1, 29-31 & 119.80 & 1035 & 4.13 & 111.6 & -64 & 94.0 & 109.2 & 1.003 \\
\hline $5 \mathrm{R}-1,104-106$ & 120.55 & 1495 & 2.72 & 50.8 & -45 & 41.9 & 55.4 & 1.004 \\
\hline 5R-2, 92-94 & 121.93 & 1450 & 1.67 & 32.2 & 5 & 57.2 & 171.8 & - \\
\hline 5R-2, 109-111 & 122.10 & 675 & 0.94 & 38.8 & 50 & 56.6 & 21.7 & 1.008 \\
\hline $5 R-3,7-9$ & 122.58 & 1061 & 3.61 & 9.5 & -32 & 93.5 & 126.7 & 1.014 \\
\hline $5 R-3,133-135$ & 123.84 & 1616 & 1.40 & 24.2 & -47 & - & - & 1.004 \\
\hline $5 R-4,36-38$ & 124.37 & 1073 & 4.01 & 101.4 & -55 & 70.5 & 121.0 & 1.003 \\
\hline $6 R-1,60-62$ & 129.71 & 2554 & 2.29 & 2.5 & -31 & 87.5 & 231.7 & 1.007 \\
\hline $6 \mathrm{R}-1,113-115$ & 130.24 & 2152 & 0.02 & 2.1 & -47 & 25.4 & - & - \\
\hline 6R-2, 41-43 & 131.02 & 2408 & 5.39 & 62.6 & -40 & 52.1 & 185.7 & 1.005 \\
\hline $6 \mathrm{R}-2,119-121$ & 131.80 & 1595 & 4.05 & 70.9 & -63 & - & - & 1.006 \\
\hline $6 \mathrm{R}-3,26-28$ & 132.37 & 2101 & 6.27 & 83.4 & -49 & 61.5 & - & 1.005 \\
\hline $6 \mathrm{R}-3,85-87$ & 132.96 & 1461 & 2.96 & 56.6 & -42 & 48.5 & 164.3 & 1.019 \\
\hline $6 R-4,14-16$ & 133.75 & 1626 & 2.64 & 45.3 & -46 & 23.0 & 185.3 & 1.009 \\
\hline $6 \mathrm{R}-4,88-90$ & 134.49 & 3324 & 1.82 & 15.7 & -24 & 25.3 & - & 1.006 \\
\hline $6 R-4,126-128$ & 134.86 & 2090 & 0.78 & 10.4 & -33 & - & 174.0 & - \\
\hline $7 \mathrm{R}-1,39-41$ & 139.20 & 920 & 0.89 & 27.1 & -64 & 80.0 & 125.7 & - \\
\hline $7 \mathrm{R}-1,120-122$ & 140.01 & 1253 & 0.18 & 83.4 & -64 & 50.4 & 111.4 & 1.009 \\
\hline $7 \mathrm{R}-2,21-23$ & 140.52 & 1229 & 4.33 & 98.4 & -89 & 72.0 & 123.4 & 1.005 \\
\hline $7 \mathrm{R}-2,120-122$ & 141.51 & 1467 & 0.88 & 16.8 & -48 & - & - & - \\
\hline $7 R-3,60-62$ & 142.41 & 2164 & 0.97 & 12.5 & -52 & 35.8 & - & 1.007 \\
\hline $7 R-3,135-137$ & 143.18 & 1584 & 3.34 & 58.9 & -34 & 39.5 & 191.8 & 1.017 \\
\hline $7 R-4,52-54$ & 143.83 & 2238 & 4.03 & 50.3 & -35 & 17.2 & 213.3 & 1.016 \\
\hline $8 \mathrm{R}-1,88-90$ & 149.19 & 2700 & 4.82 & 49.9 & -49 & 38.6 & 184.4 & 1.009 \\
\hline $8 \mathrm{R}-2,136-138$ & 151.17 & 2006 & 0.66 & 9.2 & -56 & 42.5 & 173.6 & - \\
\hline $8 R-3,14-16$ & 151.45 & 1245 & 0.27 & 60.9 & -29 & 34.3 & 142.3 & $\bar{m}$ \\
\hline 9R-1, 85-87 & 158.76 & 3944 & 0.52 & 3.6 & -51 & 14.5 & $\overline{0}$ & 1.008 \\
\hline $9 \mathrm{R}-2,133-135$ & 160.70 & 1229 & 0.52 & 11.8 & -49 & 51.0 & 95.8 & 1.006 \\
\hline $9 \mathrm{R}-3,48-50$ & 161.39 & 1268 & 0.18 & 3.9 & -52 & 28.3 & 123.0 & - \\
\hline $10 \mathrm{R}-1,23-25$ & 167.74 & 1264 & 0.22 & 4.9 & -58 & 354 & 163.8 & 1.005 \\
\hline $10 \mathrm{R}-2,27-29$ & 169.28 & 1626 & 0.30 & 5.2 & -56 & 23.0 & - & 1.005 \\
\hline $10 \mathrm{R}-2,132-134$ & 170.32 & 1562 & - & - & - & - & - & - \\
\hline 10R-3, 134-138 & 171.85 & 1024 & 0.24 & 6.5 & -53 & 42.1 & - & 1.005 \\
\hline $10 R-4,11-13$ & 172.11 & 799 & 0.31 & 10.7 & -62 & 74.5 & 45.3 & 1.009 \\
\hline $11 R-1,40-42$ & 177.51 & 1080 & 0.11 & 2.9 & -57 & 37.7 & - & 1.005 \\
\hline $11 \mathrm{R}-2,124-126$ & 178.35 & 1498 & 0.19 & 3.5 & -55 & 38.6 & 145.8 & - \\
\hline $11 \mathrm{R}-2,50-52$ & 179.11 & 1362 & 0.19 & 3.8 & 56 & 20.4 & 120.2 & 1.012 \\
\hline IIR-2, 134-136 & 180.35 & 2074 & 3.95 & 53.4 & -48 & 22.0 & 141.0 & 1.010 \\
\hline $11 \mathrm{R}-3,84-86$ & 180.94 & 2046 & 5.31 & 72.5 & -55 & 29.8 & - & - \\
\hline $12 \mathrm{R}-1,9-11$ & 186.90 & 1406 & 0.49 & 9.8 & -51 & 37.8 & 100.2 & - \\
\hline $12 R-4,92-94$ & 191.93 & - & 0.29 & - & -55 & 39.4 & - & - \\
\hline Mean & & 1940 & 3.61 & 52.4 & -49 & 40.4 & 142.2 & 1.008 \\
\hline
\end{tabular}

the same demagnetization in order to establish the blocking temperature both of the NRM and IRM. In addition for three samples from Hole 655B, the saturation magnetization (Js) was measured as a function of temperature on a Curie Balance system.
The curves of the stepwise thermal demagnetization of NRM on samples from Hole $655 \mathrm{~B}$ show that the blocking temperatures are concentrated in the $350^{\circ}-575^{\circ} \mathrm{C}$ range. An example of such a curve is shown in Figure 13. Some curves show a small increase of $\mathrm{Jr}$ at $350^{\circ} \mathrm{C}$; all these curves belong to the upper part 


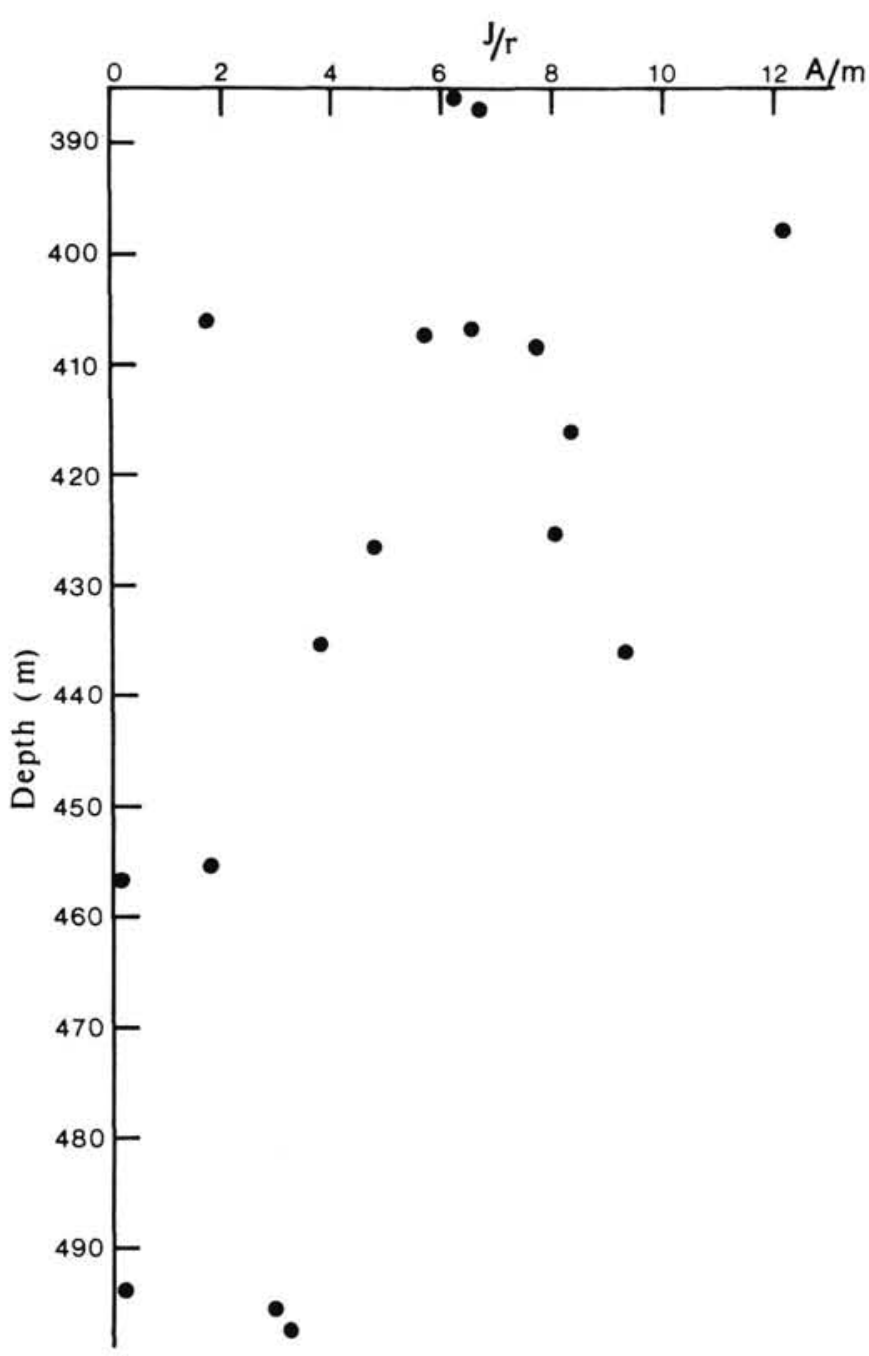

Figure 1. Intensity of NRM plotted against depth in Hole 651A.

of the section. The susceptibility increases with temperature, especially for $\mathrm{T}>350^{\circ} \mathrm{C}$ (Fig. 13), and this is a clear indication that the mineralogy is changing and the high susceptibility product is most probably magnetite. Thermal demagnetizations of IRM was carried out on five samples from Hole 651A (Fig. 14) and five samples from Hole 655B (Fig. 15). In spite of the different behavior in the acquisition of IRM, the curves of thermal demagnetization of the IRM seem more homogeneous. In Hole $655 \mathrm{~B}$ the blocking temperatures spectrum is mostly confined to $300^{\circ}$ and $500^{\circ} \mathrm{C}$. Maximum blocking temperatures of IRM and NRM is always less than $580^{\circ} \mathrm{C}$.

Thermomagnetic curves $(\mathrm{J} / \mathrm{T})$ were measured in vacuum on three samples of Hole 655B (Fig. 16) and all three curves show the same trend. In the heating curve the magnetization decreases until an initial Curie temperature at about $350^{\circ} \mathrm{C}$. Above this temperature, the magnetization increases for about $100^{\circ} \mathrm{C}$ and then decreases to a second Curie temperature in the vicinity of $575^{\circ} \mathrm{C}$. The cooling curves are completely different than the heating curves. We interpret this irreversible thermomagnetic curves as diagnostic of titanomaghemite inverting to magnetite at about $350^{\circ} \mathrm{C}$ (Redman and O'Reilly 1970; Marshall and Cox, 1972). The magnetite produced (in vacuum) has a $560^{\circ} \mathrm{C}$ Curie temperature, and shows a sharp increase in Js on cooling.

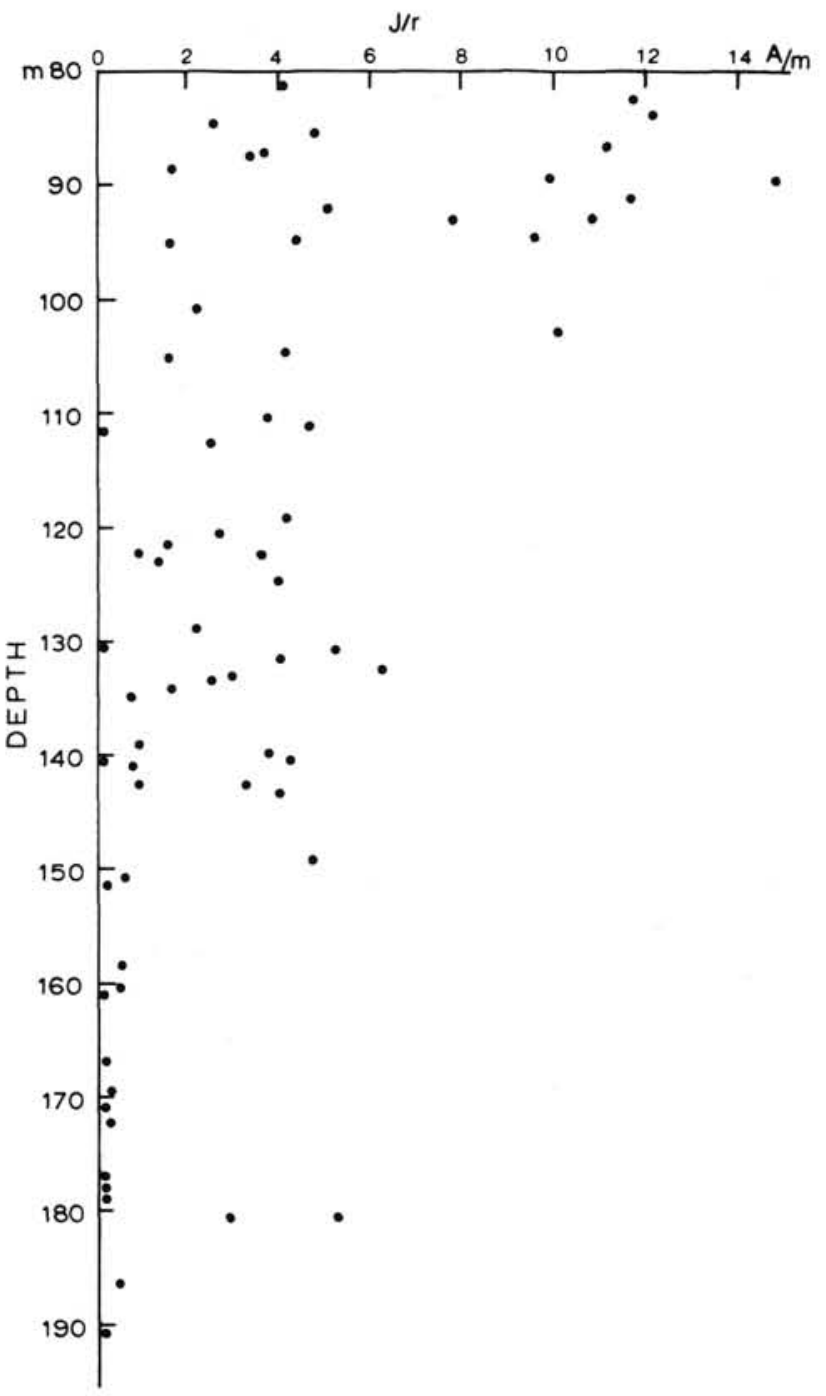

Figure 2. Intensity of NRM plotted against depth in Hole 655B.

\section{ANISOTROPY OF MAGNETIC SUSCEPTIBILITY (AMS)}

The anisotropy of magnetic susceptibility (AMS) of basaltic rocks could be caused by the net alignment of magnetic grains. It is probable that net preferred alignment can be increased in basalts by flow during emplacement. Thus AMS is possibly relevant to distinguishing between igneous emplacement modes (Elwood and Watkins, 1973; Elwood, 1975). The ratio K1/K3 is commonly used as a measure of the degree of anisotropy. In the studied samples it is very low and constant ranging from 1.003 to 1.028 , that is to say, there is practically no anisotropy in the samples. This result suggests that the emplacement was not a stress-field.

\section{OPAQUE MINERALOGY}

Twelve polished mounts were examined in reflected light at magnifications up to $\times 1000$. All the sections exhibit a very fine grain with a grain size $<2 \mu \mathrm{m}$. This made the optical observations very hard and inconclusive, and it was not possible to identify the different degree of maghemitization. The observed grain-shape is variable. Skeletal or subskeletal grains, typical of 


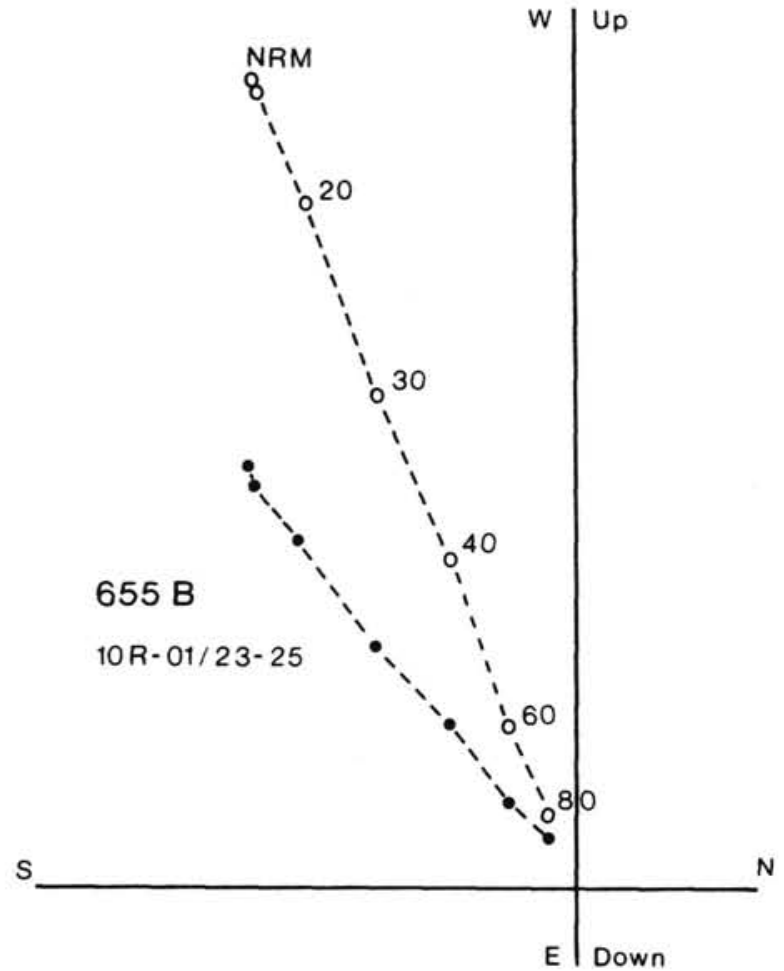

Figure 3. Zijderveld plot of the single component behavior of sample $10 \mathrm{R}-01,23-25 \mathrm{~cm}$ (Hole 655B). Numbers next to selected point refer to the peak field in milliTesla $(\mathrm{mT})$.

rapid cooling were distinguished, as well as euhedral and irregulars grains with corroded boundary or with inclusions.

\section{SUMMARY OF RESULTS}

The investigation of magnetic properties of the basalts collected by the ODP Leg 107 in Hole 651A and 655B suggests the following conclusions:

1. The basalts of Hole 651A have higher susceptibility (K) and intensity of remanence (Jr) as well as smaller median destructive field (MDF), Koenigsberger ratio (Q), and saturation remanence (Jrs) than samples from Hole 655B. All these magnetic properties exhibit a lower scatter in Hole 651A than in Hole 655B. Moreover, the basalts of Hole 651A saturated at a lower value of applied-field.

2. The stability of the remanence is high in both the sites, but the inclinations (I) of the Hole 655B are consistent with the latitude of the site, while in the Hole 651A they are systematically shallower.

3. In Hole $655 \mathrm{~B}$ the intensity of remanence (Jr), the susceptibility $(\mathrm{K})$, and the Koenigsberger ratio $(\mathrm{Q})$ decrease from the top to the bottom. In detail the hole exhibits three trends along the section, so that it is possible to distinguish three magnetic units: (1) an upper unit from 81.35 to 105.17 mbsf characterized by high and scattered values of intensity of NRM (mean 6.65 $\mathrm{A} / \mathrm{m}$ ), magnetic susceptibility (mean $2467 \times 10^{-6}$ S.I. units), and Koenigsberger ratios (mean 89.1) but lower and less scattered values of the median destructive field (mean $31.4 \mathrm{mT}$ ); (2) A middle unit from 110.14 to 151.45 mbsf with lower values and scattering of $\mathrm{Jr}$ (mean $2.65 \mathrm{~A} / \mathrm{m}$ ), $\mathrm{K}$ (mean $1726 \times 10^{-6}$ S.I. units), Q (mean 62.2), but with the highest most variable values of MDF (mean $52.8 \mathrm{mT}$ ). The basalts of this unit were saturated in field as strong as $0.4-0.5 \mathrm{~T}$; (3) A lower unit, from
158.76 mbsf to the bottom of the section (191.93 mbsf), characterized by more consistent values of the magnetic properties which show a significant decrease of $\mathrm{Jr}$ (mean $0.86 \mathrm{~A} / \mathrm{m}$ ), lower values of $\mathrm{K}$ (mean $1584 \times 10^{-6}$ S.I. units), and $\mathrm{Q}$ (mean 14.8) while the MDF (mean $35.3 \mathrm{mT}$ ) is comparable with the upper unit.

Thermal demagnetizations on samples from Hole 655B have shown blocking temperatures ranging between $350^{\circ}$ and $575^{\circ} \mathrm{C}$. This range of temperatures is comparable with the values found by Irving et al. (1970) on basalts recovered at some distance from the Mid-Atlantic ridge axis. Younger rocks show lower blocking temperatures.

Thermomagnetic curves have clearly shown irreversibility, indicating presence of titanomaghemite as product of low-temperature oxidation.

\section{DISCUSSION}

The magnetic properties of the studied basalts seem to indicate that the magnetic carrier is a fine grain titanomagnetite which has experienced a significant degree of low temperature oxidation (maghemitization) which produced titanomaghemite.

A number of physical features of titanomaghemite is known to affect magnetic properties. Some are obvious, such as abundance, while others are less obviously related, such as grain size and degree of oxidation. Therefore it is difficult to know if the observed magnetic changes are due mainly to the oxidation or to grain-size effects. The problem is to separate the effect of these different variables.

The magnetic effect of maghemitization is strongly dependent on the grain size of the original unoxidized titanomagnetite, in fact the maghemitization produces different effects if the grain size is in the single-domain (SD) or the multidomain (MD) range.

In spite of the number of studies on the magnetic effect of maghemitization of oceanic basalts, there still does not exist an agreement on these effects. The only agreement is on the decrease of the remanence intensity (Jr) with the oxidation (Sakamoto et al., 1968; Irving, 1970; Ryall and Ade-Hall, 1975; Johnson and Atwater, 1977; Smith, 1983; Beske-Diehl and Soroka, 1984). The relationships between susceptibility and oxidation parameter, and between coercive force and oxidation parameter are not straight line relationships. Experimental data on synthetic samples indicate an increase followed by a decrease in coercive force as the oxidation parameter increases. Conversely, the experimental data suggest that the susceptibility decreases and then increases as the oxidation parameter increases $(\mathrm{Oz}$ demir and O'Reilly, 1982; O'Reilly, 1984).

The magnetic susceptibility was found to decrease in oxidized rocks with single-domain (SD) grain size by Johnson and Atwater (1977), Marshall (1978), and Beske-Diehl and Soroka (1984). However, Prevot et al. (1981) and Smith (1983) found an increase of the susceptibility for SD grains while a decrease was found for multidomain (MD) grains. The Koenigsberger ratio (Q) is related to the intensity of the NRM and to the susceptibility (K). It seems well accepted that during maghemitization, in SD grains, $Q$ decreases because the intensity of the remanence decreases more rapidly than the susceptibility. In MD grains, the measured $Q$ value suggests that this parameter remains more or less constant during low temperature oxidation (Ade-Hall et al., 1976; Marshall, 1978; Prevot et al., 1981).

More questionable is the effect of the maghemitization on the coercivity. Readman and O'Reilly (1972), Moskovitz and Banerjee (1981), Prevot et al. (1981), and Smith (1983) observe a decrease of the coercivity in SD grains. The opposite trend is shown by Johnson and Atwater (1977), Marshall (1978), and 
A

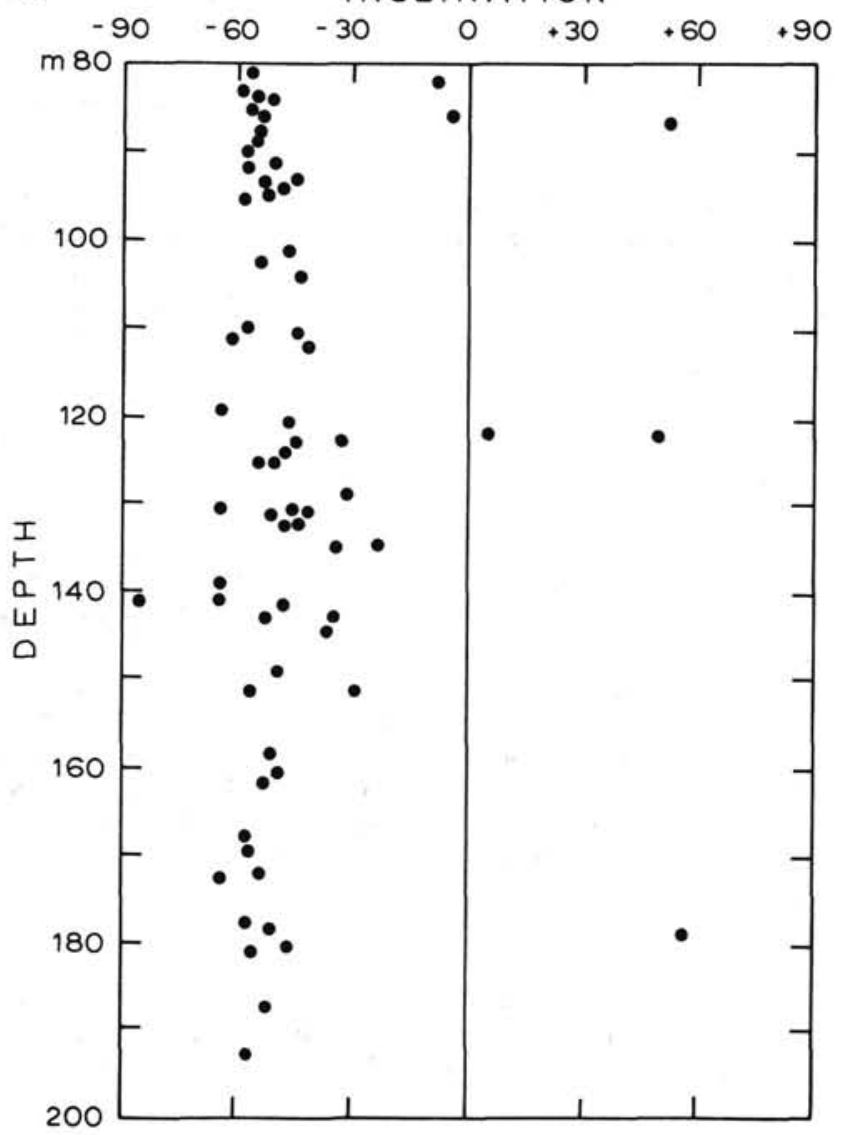

B

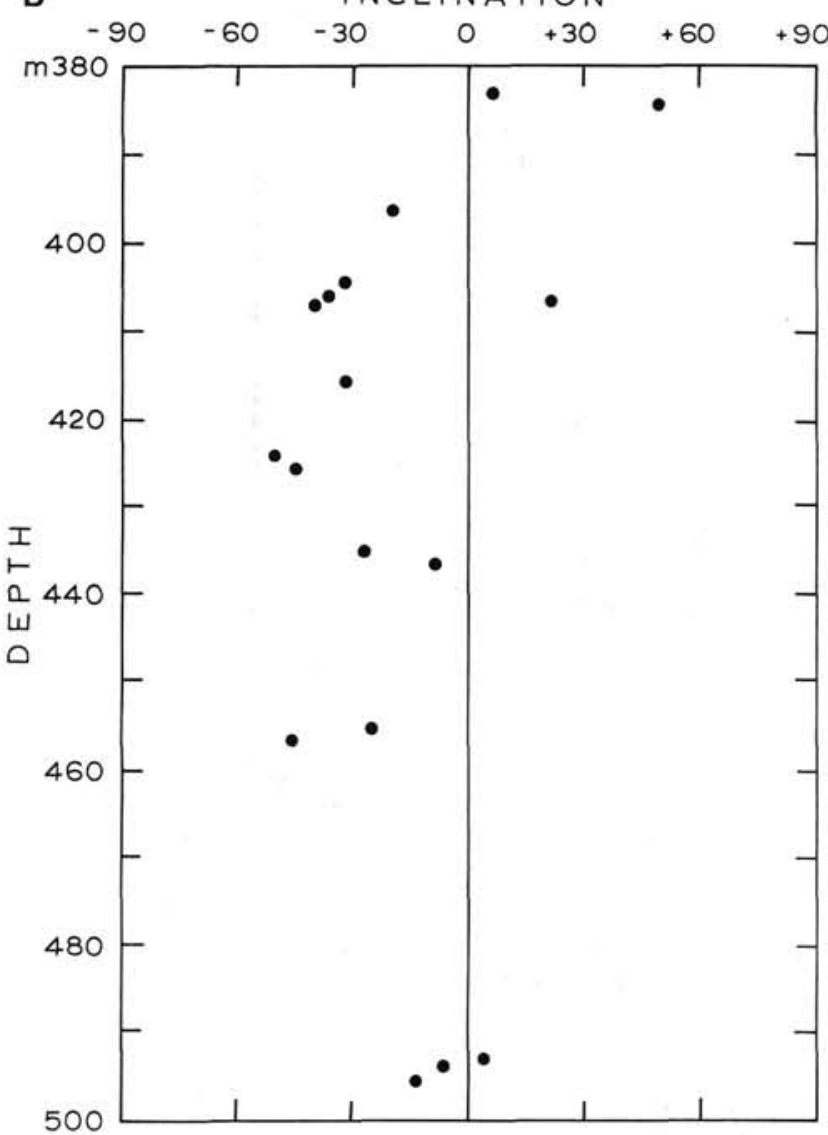

Figure 4. A. Stable inclinations plotted against depth in Hole 655B. B. Stable inclinations plotted against depth in Hole 651A.

Beske-Diehl and Soroka (1984). On this basis, it is difficult to say if the basalts of the Hole 651A are more or less oxidized than those of the Hole 655B.

The irreversibility of thermomagnetic curves and the high Curie temperature of the basalts of Hole $655 \mathrm{~B}$ are clear evidence of low-temperature oxidation. The observed trends of the magnetic properties down the section, and especially the significant decrease in the intensity of the NRM, could be interpreted as an increasing maghemitization with the depth. The increasing oxidation could be a function of the age.

\section{ACKNOWLEDGMENTS}

We want to thank Prof. C. Laj (CNRS-Paris), and Prof. K. Kobayashi and Dr. T. Furuta (ORI of Univ. of Tokyo) for the use of their respective laboratories.

This paper was supported by Contribution No. 684 of the Institute of Marine Geology, CNR, Bologna, Italy.

\section{REFERENCES}

Ade-Hall, J. M., Johnson, H. P., and Ryall, P.J.C., 1976. Rock magnetism of basalts, Leg 34. In Yeats, R. S., Hart, S. R., et al., Init. Repts. DSDP, 34: Washington (U.S. Govt. Printing Office), 459468.

Beske-Diehl, S. J., and Soroka, W. L., 1984. Magnetic properties of variably oxidized pillow basalt. Geophys. Res. Lett., 11:225-228.

Elwood, B. B., 1975. Analysis of emplacement mode in basalt from Deep-Sea Drilling Project Holes 319A and 321 using anisotropy of magnetic susceptibility. J. Geophys. Res., 80:4805-4808.

Elwood, B. B., and Watkins N. D., 1973. Anisotropy of magnetic susceptibility end emplacement modes of submarine igneous rocks. Am. Geophys. Union Trans., 54:95-96.
Irving, E., 1970. The mid-Atlantic ridge at $45 \mathrm{~N}$. XIV. Oxidation and magnetic properties of basalt; review and discussion. Can. J. Earth Sci., 7:1528-1538.

Irving, E., Robertson, W. A., and Aumento, F., 1970. The mid-Atlantic ridge near $45 \mathrm{~N}$. VI. Remanent intensity, susceptibility, and iron content of dredged samples. Can. J. Earth Sci., 7:226-238.

Johnson, H. B., and Atwater T., 1977. Magnetic study of basalts from the mid-Atlantic ridge, lat. 37 N. Geol. Soc. Am. Bull., 88:637-647.

Lowrie, W., 1977. Intensity and direction of magnetization in oceanic basalts. J. Geol. Soc. London, 133:61-82.

Marshall, M., 1978. The magnetic properties of some DSDP basalts from the North Pacific and inferences for Pacific plate tectonics. $J$. Geophys. Res., 83:289-308.

Marshall, M., and Cox, A., 1972. Magnetic changes in pillow basalts due to seafloor weathering. J. Geophys. Res., 77:6459-6469.

Moskowitz, B. M., and Banerjee, S. K., 1981. A comparison of the magnetic properties of synthetic titanomaghemites and some oceanic basalts. J. Geophys. Res., 86:11869-11882.

O'Reilly, W., 1984. Rock and Mineral Magnetism. New York (Chapman and Hall), 1-220.

Ozdemir, O., and O'Reilly, W., 1982. Magnetic hysteresis properties of synthetic monodomain titanomaghemites. Earth Planet. Sci. Lett., 57:437-447.

Prevot, M., Lecaille, A., and Mankinen, E. A., 1981. Magnetic effects of maghemitization of oceanic crust. J. Geophys. Res., 86:40094020.

Readman, P. W., and O'Reilly, W., 1970. The synthesis and inversion of non-stoichiometric titanomagnetites. Phys. Earth Planet. Inter., 4: 121-128.

Readman, P. W., and O'Reilly, W., 1972. Magnetic properties of oxidized (cation-deficient) titanomagnetites $(\mathrm{Fe}, \mathrm{Ti},)_{3} \mathrm{O}_{4}$. J. Geomagn. Geoelectr., 24:69-90. 
Ryall, P.J.C., and Ade-Hall, J. M., 1975. Radial variation of magnetic properties in submarine pillow basalt. Can. J. Earth Sci., 12:19591969.

Sakamoto, N., Ince, B. I., and O'Reilly W., 1968. The effect of wetgrinding in the oxidation of titanomagnetites. Geophys. J. R. Astron. Soc., 15:509-515.

Smith, B., 1983. Effets de la maghemitisation des titanomagnetites sur les proprietes magnetiques des basaltes sous-marins: synthese et resultats relatifs aux basaltes du Leg 51. Sci. Geol. Bull., 36:117-137.

Date of initial receipt: 18 November 1987

Date of acceptance: 13 January 1989

Ms 107B-165

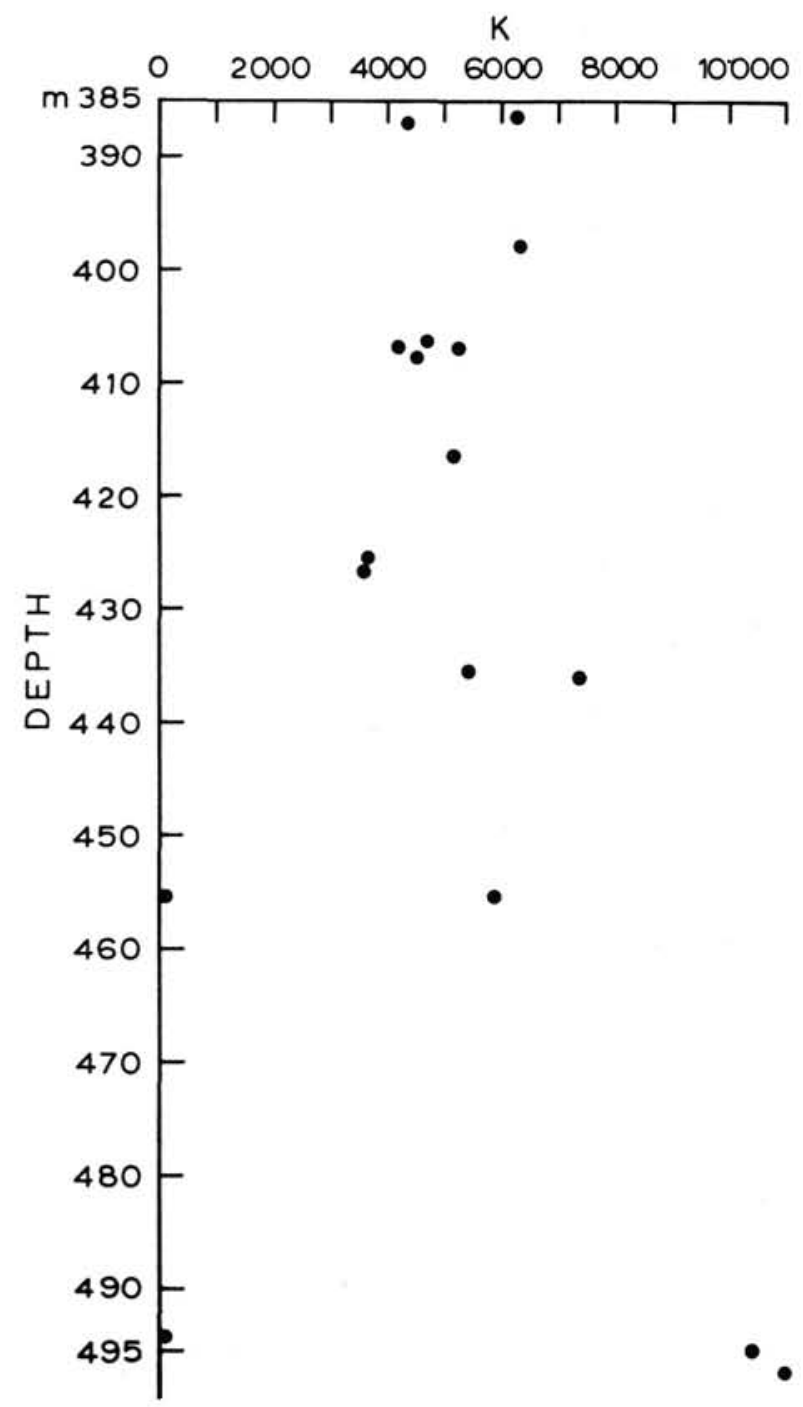

Figure 5. Magnetic susceptibility $\left(\times 10^{-6}\right.$ S.I. units) plotted against depth in Hole 651A.

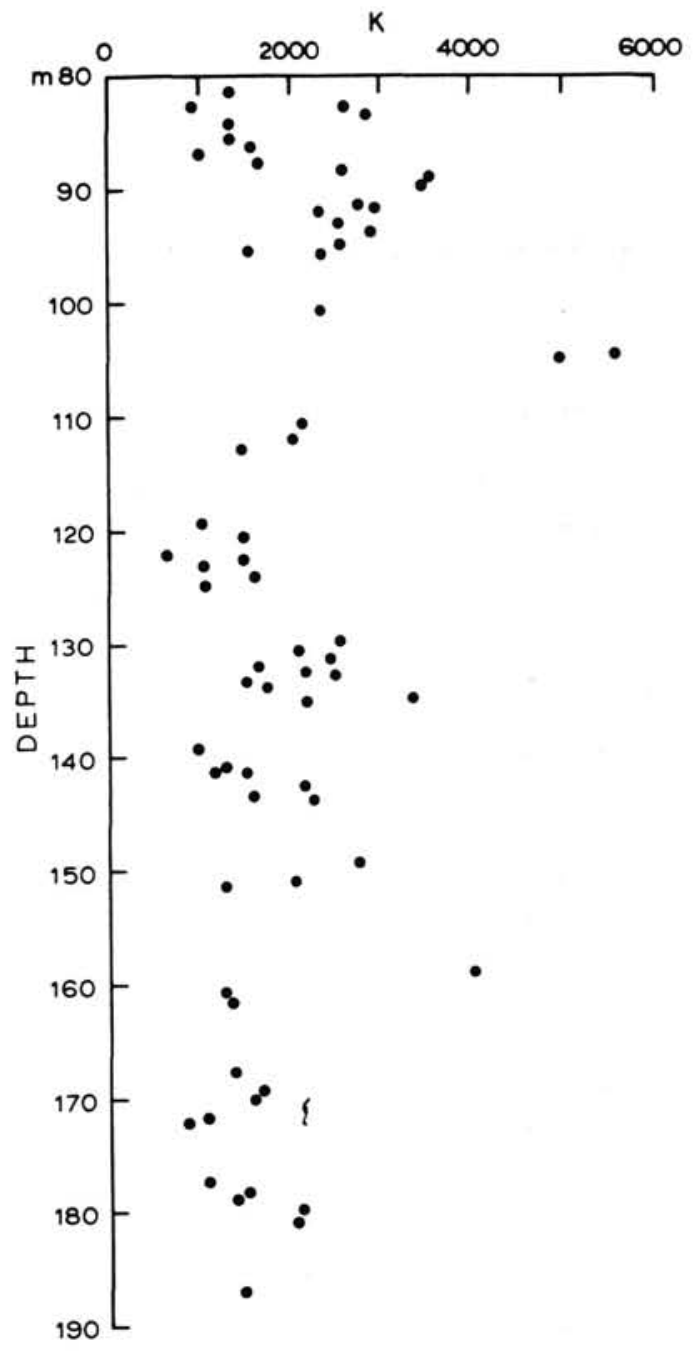

Figure 6. Magnetic susceptibility $\left(\times 10^{-6}\right.$ S.I. units) plotted against depth in Hole 655B. 
L. VIGLIOTTI, M. TORII, J. CHANNELL

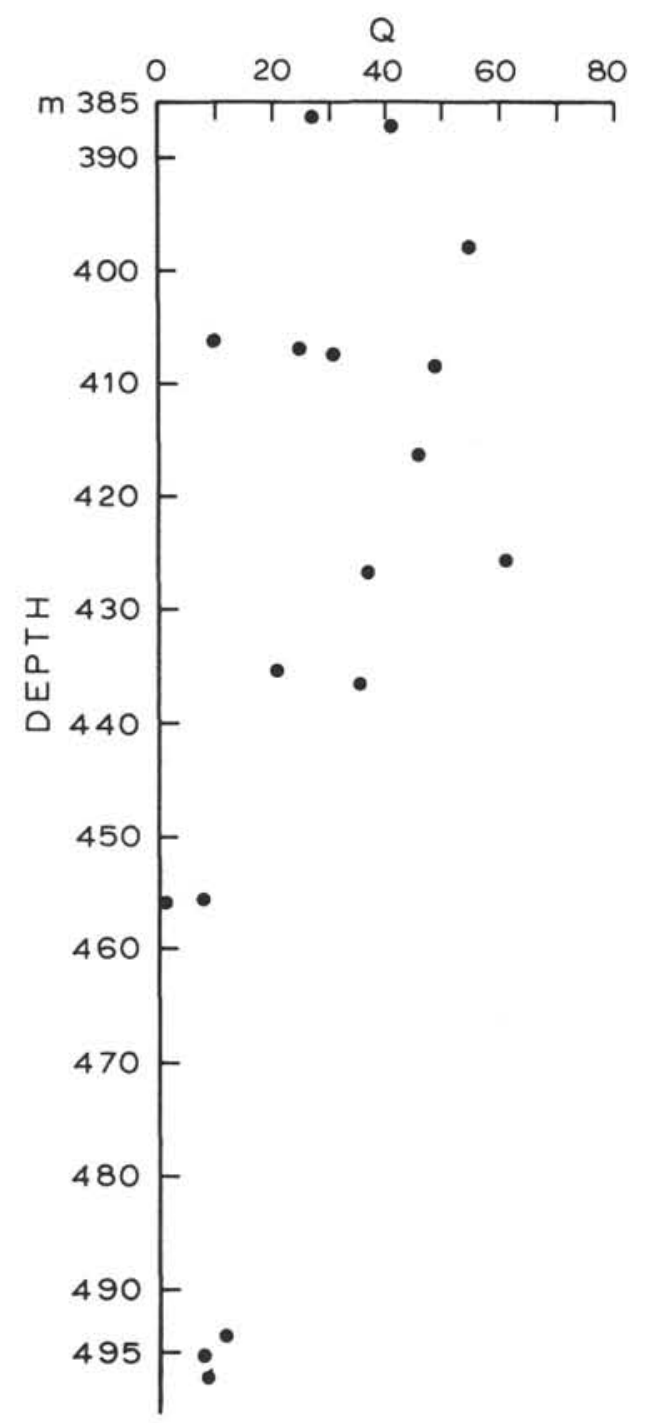

Figure 7. Koenigsberger ratio plotted against depth in Hole 651A.

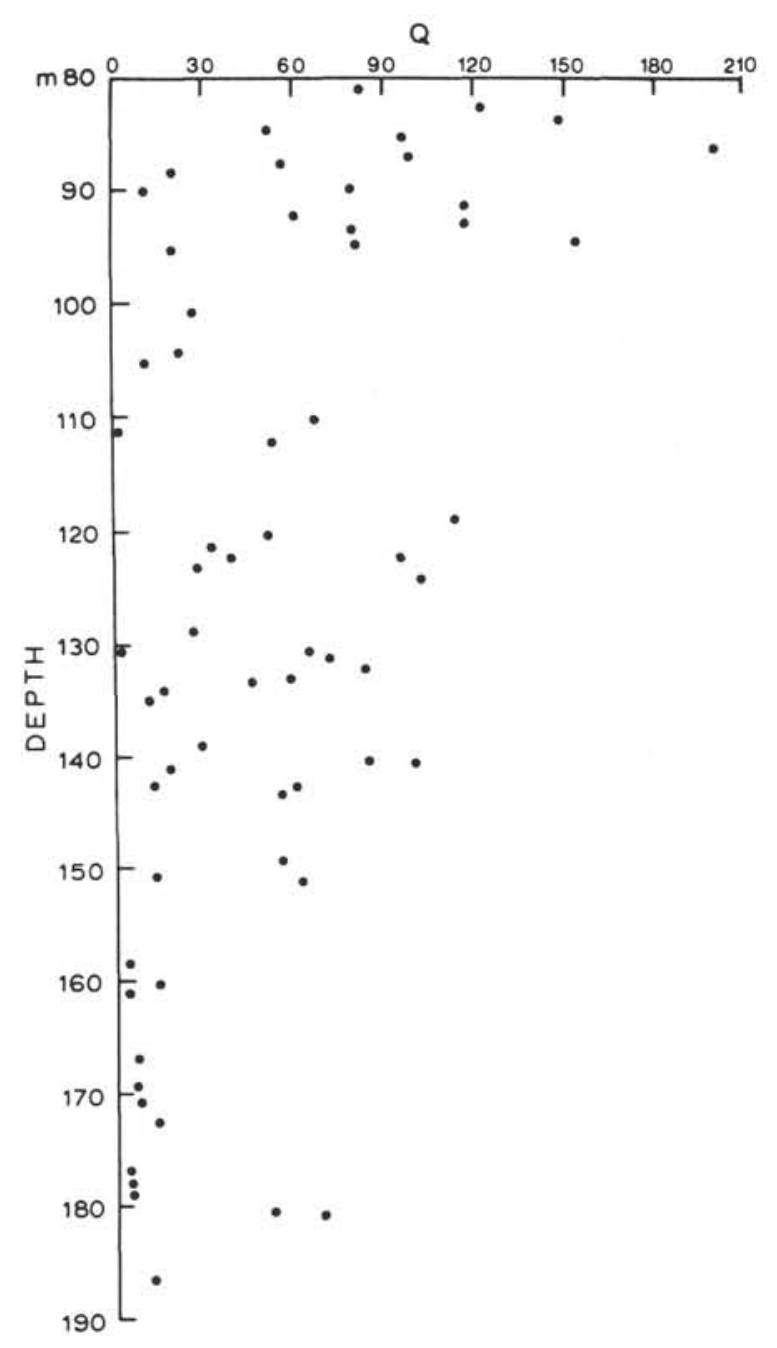

Figure 8. Koenigsberger ratio plotted against depth in Hole 655B. 


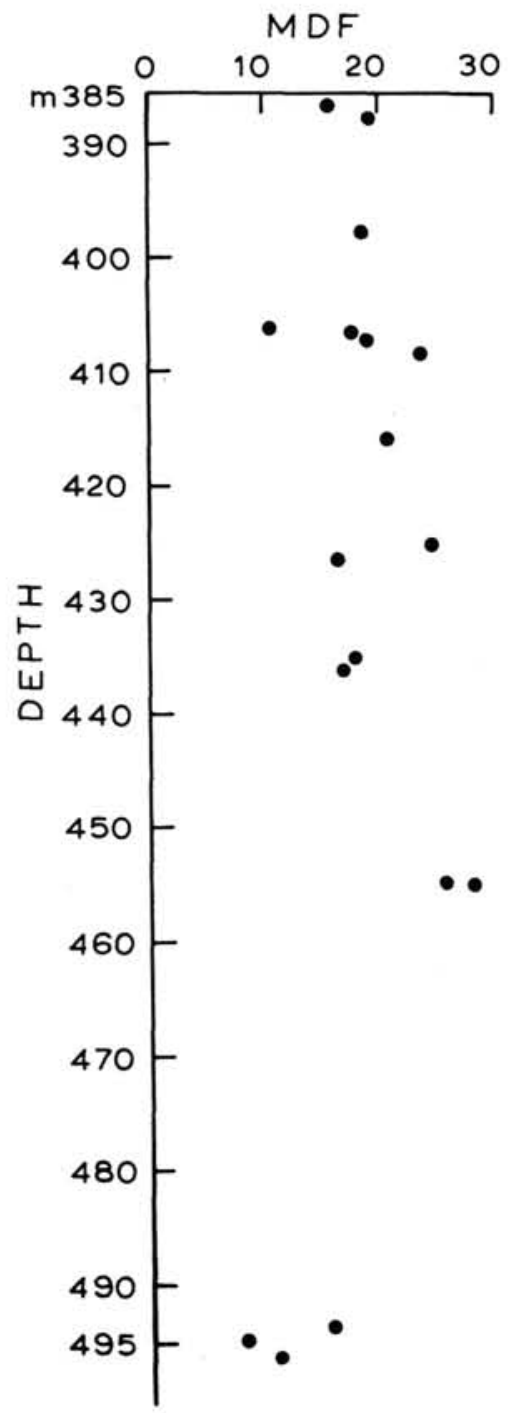

Figure 9. Median Destructive Field (values in $\mathrm{mT}$ ) plotted against depth in Hole 651A.

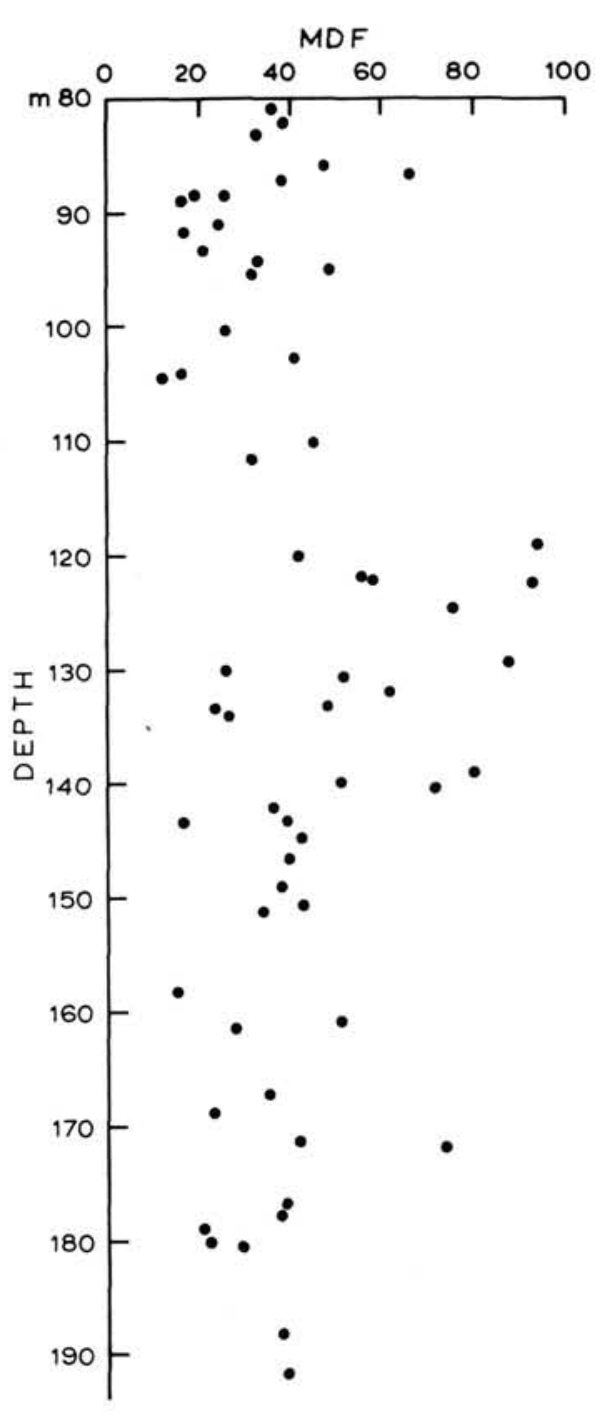

Figure 10. Median Destructive Field (values in $\mathrm{mT}$ ) plotted against depth in Hole 655B. 


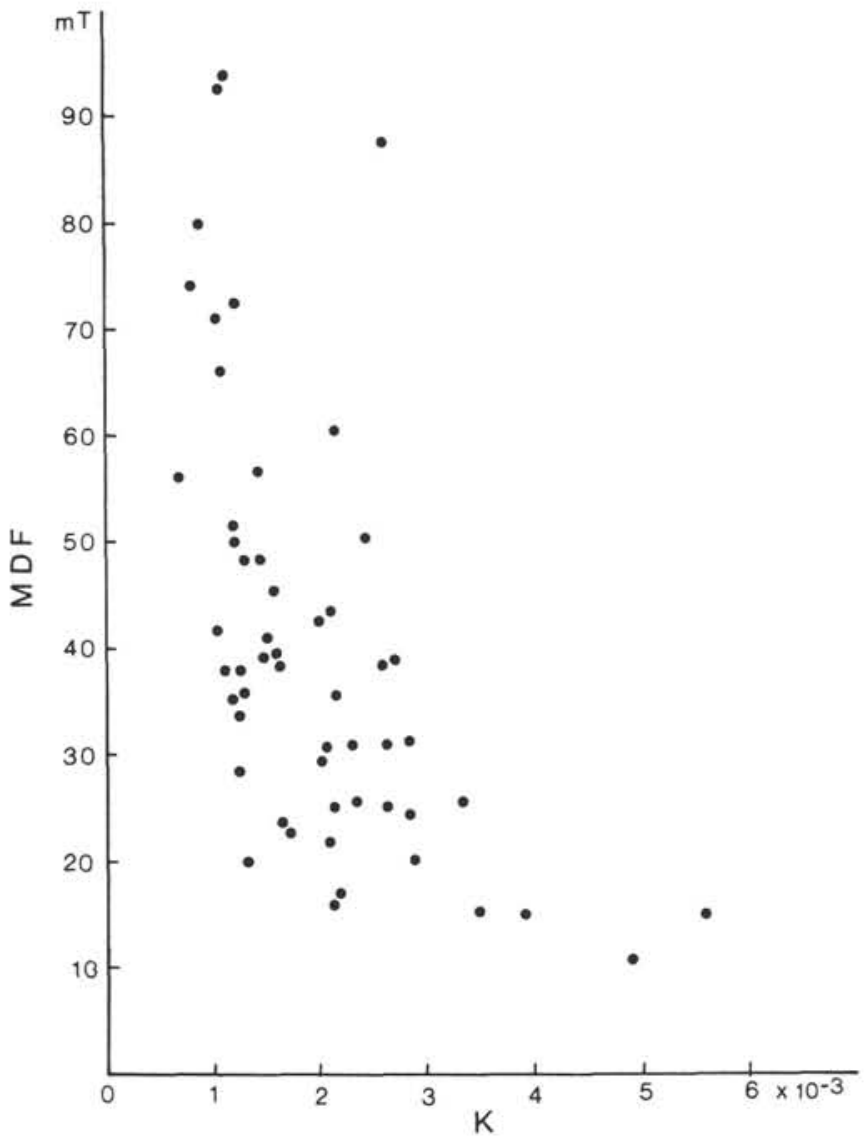

Figure 11. Correlation between Median Destructive Field (MDF) and susceptibility in basalts from Hole 655B. 

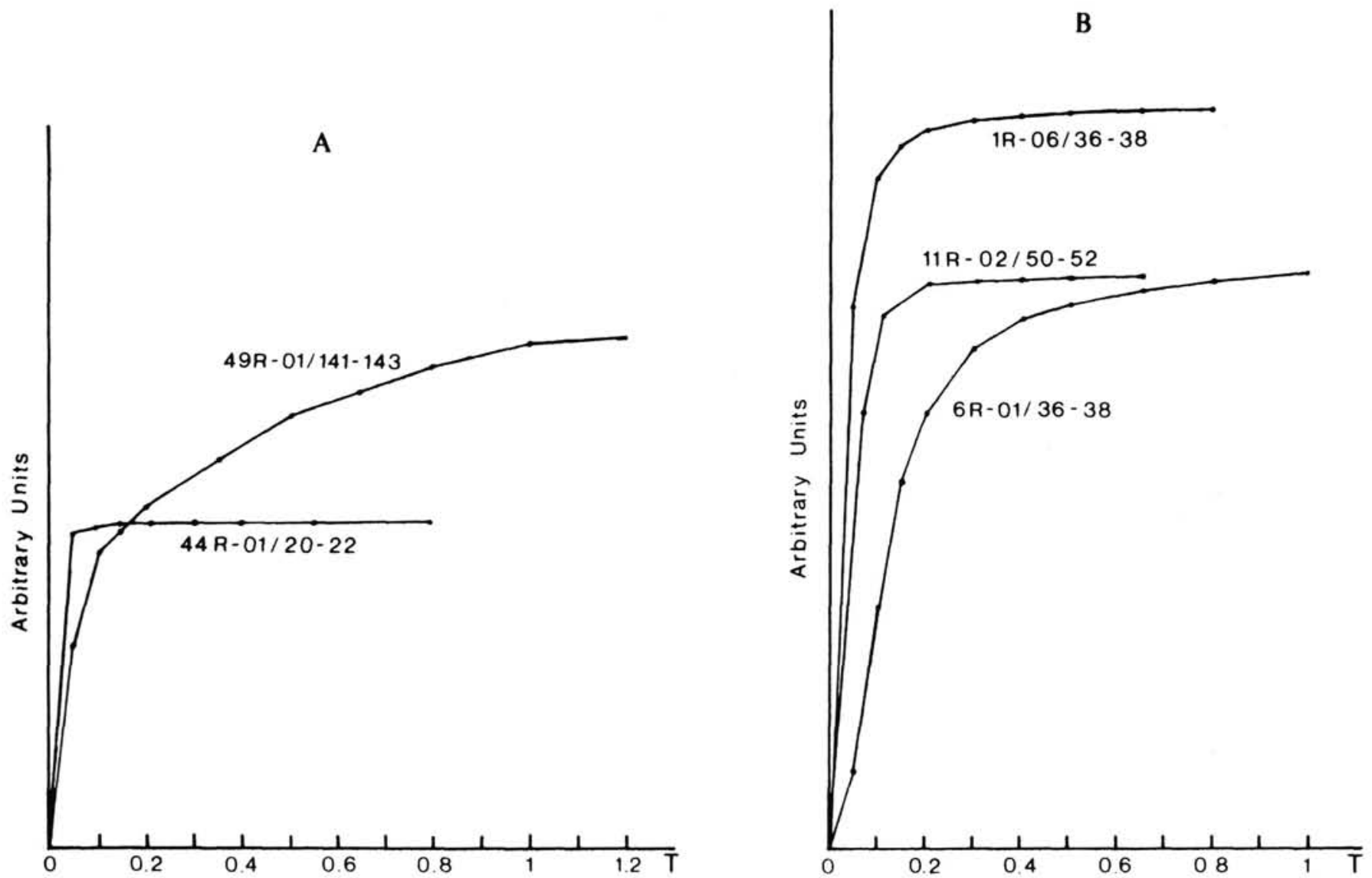

Figure 12. Typical acquisition curves of Isothermal Remanent Magnetization (IRM) for basalt samples. A. Hole 651A. B. Hole 655B.

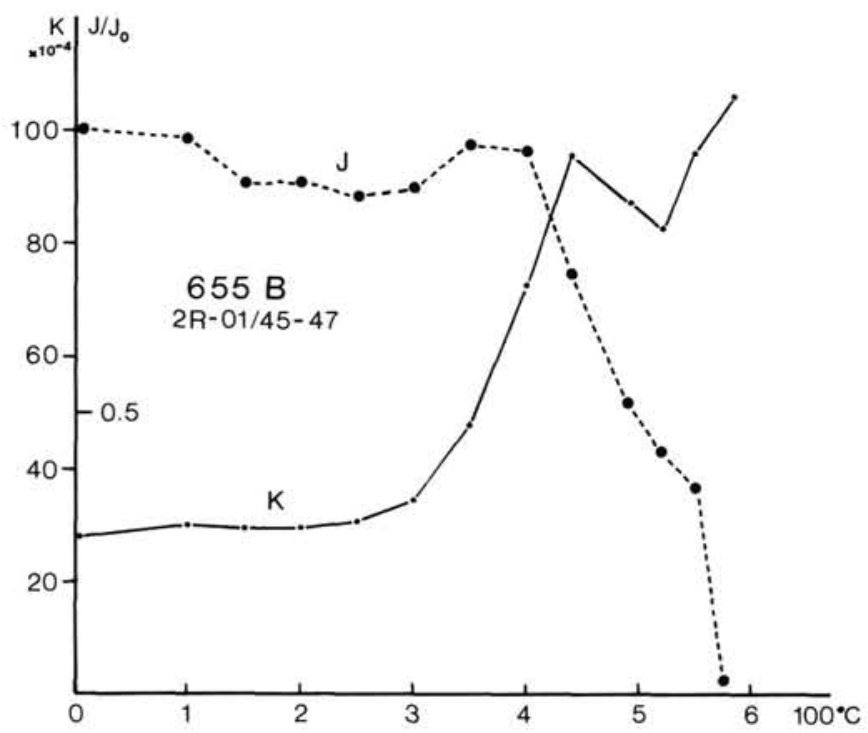

Figure 13. Stepwise thermal decay curve of the remanent magnetization (Jr) and corresponding susceptibility (K) values of Sample 2R-01, 45-47 $\mathrm{cm}$, from Hole 655B.

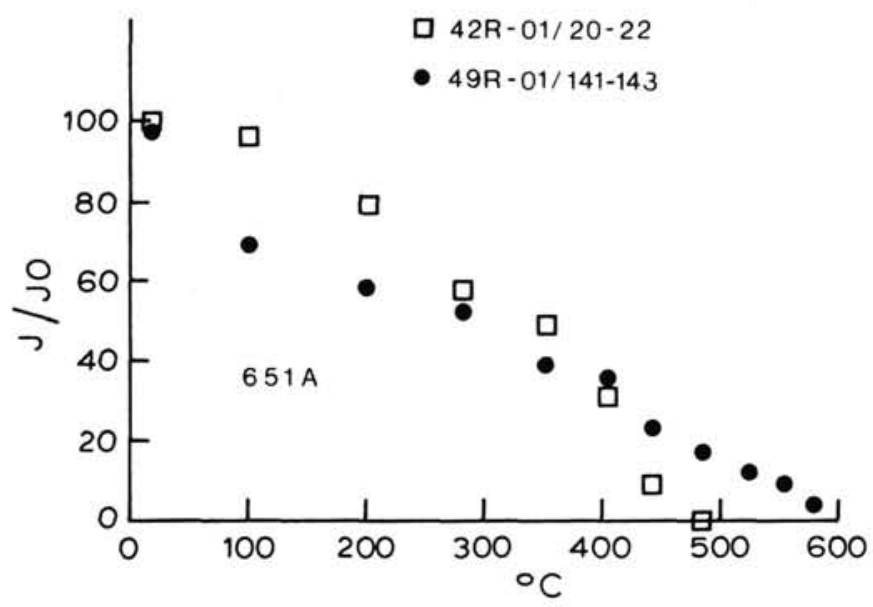

Figure 14. Typical stepwise thermal decay curves of the IRM for Hole 651 A. 
L. VIGLIOTTI, M. TORII, J. CHARNEL

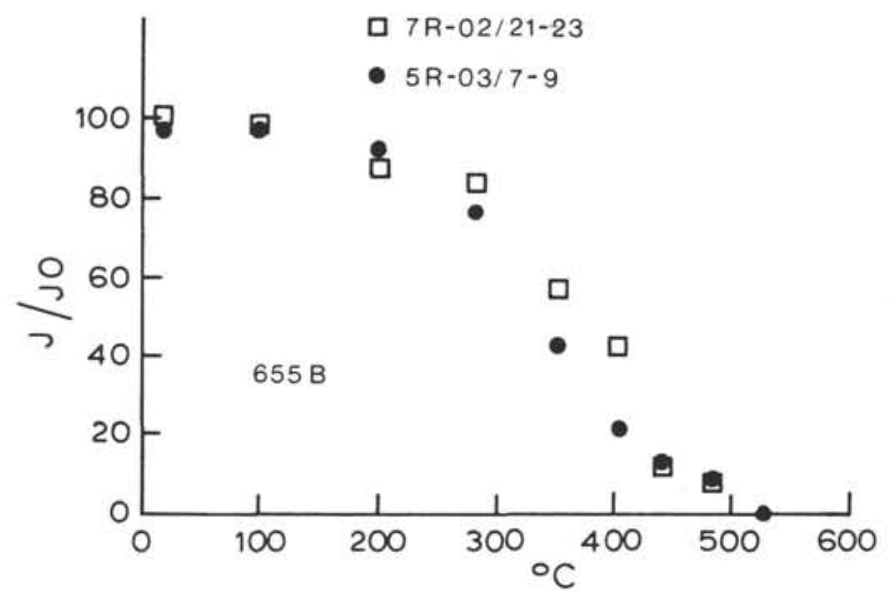

Figure 15. Typical stepwise thermal decay curves of the IRM for Hole $655 \mathrm{~B}$.
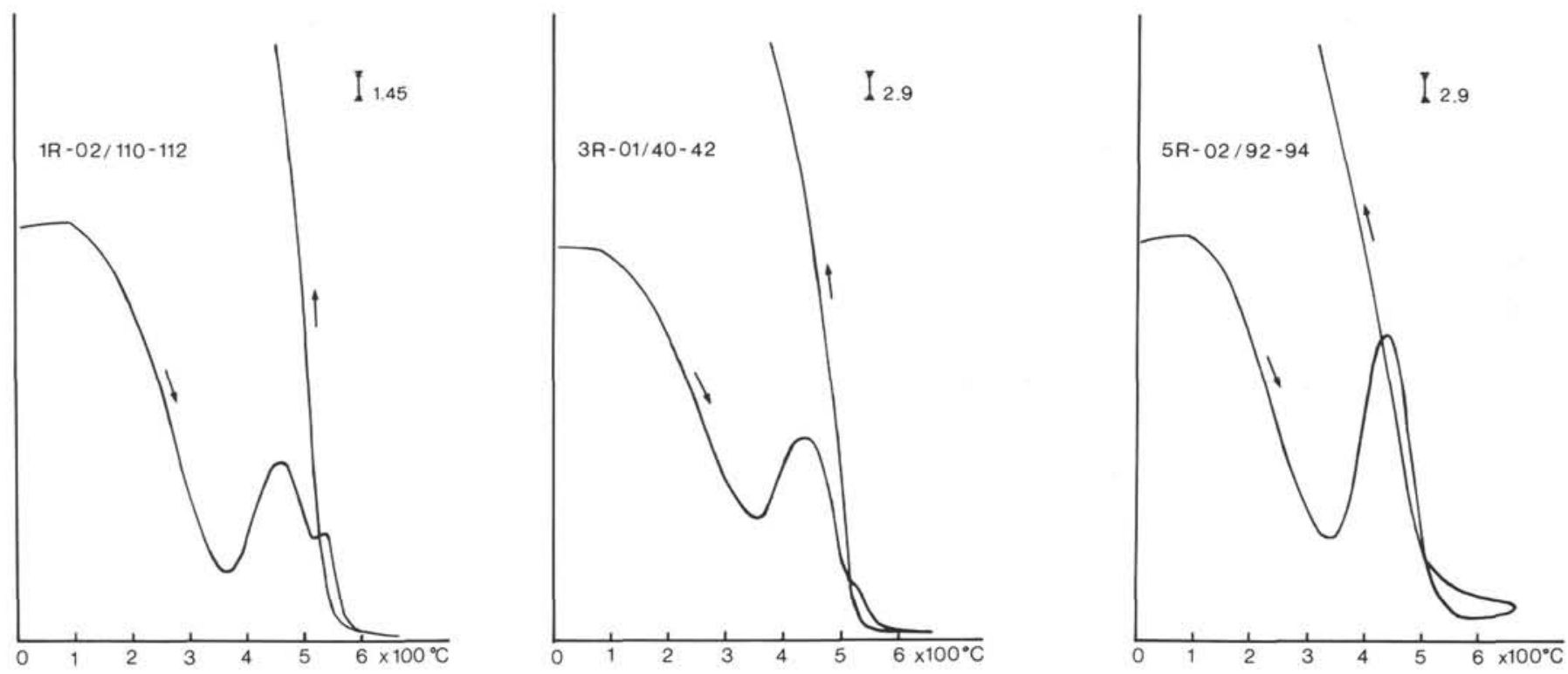

Figure 16. Typical thermomagnetic curves representative of basalts from Hole $655 \mathrm{~B}$. Heating and cooling were performed in vacuum $\left(1 \times 10^{-6}\right.$ Torr) in a field of $1 \mathrm{~T}$.

110 